\title{
SEX OFFENSES: THE SCANDINAVIAN EXPERIENCE
}

\author{
GroRg K. STüruP*
}

\section{INTRODUCTION}

Despite the broad assumption that there is a special emancipation in sexual matters in Scandinavia, there is still in many circles a tendency to deprecate sex problems and generally to de-emphasize the importance of sex in life. Nevertheless, it is clear that great changes have occurred in the thinking of large segments of the population during the last generation-changes conducing a more realistic evaluation of sex and its role in daily living. This does not mean that actual sexual behavior has become significantly more promiscuous-for, indeed, there is no proof at all of this. It rather means that concealment and the so-called double standard are no longer generally sanctioned; and those who still adhere to these norms no longer assert them quite as dogmatically, but appear to recognize the possibility that their point of view may not be infallible or at least exclusively valid. There still exists, however, a widespread anxiety concerning the results of child-seduction and the more obvious manifestations of childhood sexuality, which is reflected in strong reactions to sexual assault on children.

In explaining the approach to sex criminality in Scandinavia to a foreign audience, it is perhaps necessary to point out that Scandinavia is not a political entity, but several independent countries. Difficult as it is to discuss the more signficant aspects of a subject such as this with respect to one's own country, it is even more difficult to discuss them with respect to a foreign country, even where one feels a general familiarity with the matter. Accordingly, the primary focus of this article will be Denmark. A few general words will, however, be said about attitudes towards sex problems in Scandinavia-and especially about the elements that are contributing to their rapidly-changing complexion. In this connection, the writer will disregard the considerable modifications in social structure that are occurring in different societies all over Europe-e.g., increasing urbanization-and will advert only to the more distinctive developments in Denmark and, to a lesser extent, in Norway and Sweden.

\section{The Contemporary Scene}

\section{A. Sex Education}

In the last generation, sex education has been taught not only in the few private schools that exist in Denmark, but also in many public schools and training colleges as well, often-especially in those schools that are regarded as the pacesetters-in quite a complete and realistic way.

- M.D. 1929, University of Copenhagen. Director, Institution for Criminal Psychopaths, Herstedvester near Glostrup, Denmark; Member, Board of Directors, International Society of Criminology. Contributor to criminological and psychiatric publications. 
For the general public, too, there have become available, apart from enormous tomes that are much too expensive for the ordinary man and contain far too much about sexual abnormalities and illnesses, a large number of inexpensive, sober, and instructive smaller books. ${ }^{1}$ These are not only widely sold in bookshops, but are also found in the numerous public libraries spread all over the country. They contain in addition to a simple and sensible explanation of the anatomy of the sexual organs and their physiology-a subject that is omitted, partially or completely, in the older schoolbooks and many of the new ones-an explanation as well of intercourse, fertilization, and the unfortunately still not quite foolproof means of contraception.

These books generally emphasize the following main points:

The sexual urge is a huge power of nature that is initiated and sustained by a chemical mechanism; it is a hormonal function. In the lower animals, propagation is assured through this complex mechanism, which works like a chemical switch: first, hormone production; then, attraction of a partner in a corresponding phase; and then, conception. The higher animals have more highly-developed nervous systems, and because of this, the feelings and associations that characterize the sex life of man arise. The sexual urge becomes, owing to its meaning for propagation as well as these psychic elements, an important factor in the life of the community, and sex life becomes governed by fixed cultural rules. These rules decide which sexual stimuli are culturally acceptable and contribute beneficially to daily interpersonal relations.

One should have no illusions, however, as to the constructive results of an education of this kind. There is still, in general, an astonishing lack of knowledge concerning sex, and few yet talk freely about it. Not until there is produced a generation of parents so free from fear of sex that they can raise their children without transmitting this fear to them will the lingering hypocrisy and evasiveness significantly decrease.

Some of these books that try to develop a healthy attitude towards sex also briefly mention the most important sexual abnormalities. Homosexuality, which is caused by an interplay between natural capacities and environment, is thus referred to as a stressful deviation for the person concerned that in itself does not entail any social risk. There is no responsible person in Scandinavia who would advocate a law imposing sanctions on homosexual activities between adults. The relatively harmless forms of exhibitionism are also mentioned, and the character of the masochisticsadistic mechanism is suggested. For those who see human behavior in terms of stimulus-response, it is pointed out as well that from a purely biological point of view, there are times when the sexual urge is especially pronounced, when a very slight stimulus can trigger a disproportionate response and easily cause behavior that

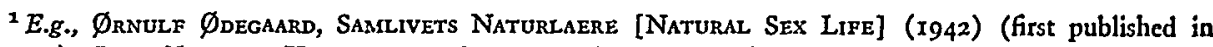
Norway); John Takman, Ungdommens Seksuelle Problemer [Sexual. Problems of Youth] (1949) (first published in Sweden); Henrik Hoffmeyer, SEksualoplysRing for UNGe [Sexual INFormation For Young People] (I948). For the very young, see, e.g., Sten Hegler, Hvordan, Mor? [How, MoTher?] (I949). 
shortly thereafter will seem quite unreasonable to everyone-including the actor.

Twelve years ago, for the first time, the facilities of the Danish radio were made available for the wider dissemination of sex information and the encouragement of discussion of sex problems. Seven programs were broadcast-all quite frank and all at the best listening time in the evening. The series was concluded with two round table discussions about sex education in schools and about sex life in society. ${ }^{2}$

\section{B. Current Sex Problems}

Two sex problems that are currently exciting much interest and discussion are the legalization of certain abortions, and the prevalence of premarital sexual relations.

\section{r. Legal abortions}

In the years following World War I, there arose in Denmark a wave of public feeling against the rather strict penalties that might be imposed for the offense of induced abortion. At that time, there was a rule of jus necessitatis, according to which abortion might be induced only where necessary to save a woman's life. This rule soon came to be interpreted differently, however, and convictions grew difficult to come by, especially at the hands of a jury. The reduction of penalties for the offense that had been effected in $1930^{3}$ was not enough to arrest this trend, and in 1932 , a commission was appointed to frame what was to become the pregnancy law of 1937.

Under this law, a mothers' aid institution that previously had been organized and operated by a private association was legalized. Since then, it has developed very rapidly, as has a similar institution in Sweden. Although its clientele initially was mostly unwed women applying for abortions, three-fourths of those now seeking its assistance are married. In sixty per cent of these latter cases, no basis for abortion is found; and of these, seventy to eighty per cent carry their babies to term. ${ }^{5}$

The law has recently been formally changed, ${ }^{6}$ but the substance remains the same. Abortion can only be obtained when:

a. It is necessary to avert serious danger or loss of the woman's life. .This judgment is based on all relevant facts, including the circumstances under which the woman has to live. Consideration is accorded not only physical or psychic illnesses, but also present or threatening weakness of a physical or psychic nature. The decision is made by a special committee consisting of the

These have been published as Georg K. Stürup (Ed.), 5 LaEger om Aegteskabets Problemer [5 Doctors on Problems of Marriage] (r947).

${ }^{3} \mathrm{Law}$ No. 126 of April 15, 1930, [1930] Lovtidende \$ A, at 697 (Den.); cf. Law No. I27 of April 15, 1930, [1930] Lovtidende § A, at 754 (Den.)

- Law No. 163 of March 18, 1937, [1937] Lovtidende $\$$ A, at 887 (Den.); cf. Law No. I19 of March 15, 1939, [1939] Lovtidende $\$$ A, at 349 (Den.)

'For more extended discussion, see Skalts, Svangerskabslov og Mødrehjaelpslov [Pregnancy Law and Mothers Aid Law], 33 Socialt Tidskrift I (1957); of. Martin Ekblad, Induced Abortion on Psychiatric Grounds: A Follow-Up Study of 479 Women, Acta Psychiat. et Neurod. (Supp. No. 99, 1955).

${ }^{\circ}$ Law No. 177 of June 23, 1956, [1956] Lovtidende $\$$ A, at 405 (Den.). 
head of the mothers' aid institution (often a social worker), a psychiatrist, and a surgeon (gynecologist).

b. The pregnancy has resulted from a criminal act-e.g., incest, rape, or intercourse with a child under fifteen years of age.

c. There is serious risk of abnormal offspring-e.g., an hereditary indication.

d. Serious psychic or physical defects or other medical indications render the woman unfit to care for the child-e.g., if the woman is a mental defective.

Abortion has never been an ideal solution, and more satisfactory alternatives are still being sought. In this connection, the mothers' aid institution has started an information service and has developed other forms of aid for pregnant women. For example, it fights the prejudice against illegitimate children; it has secured for unwed mothers the right, if they wish, to be called "Mrs." in public offices; and it has established family-oriented out-patient facilities, where social and medical advice, including instruction in the effective use of contraceptive techniques, and some psychiatric group-counseling are made available.

Legal abortions in Denmark number about 5,000 a year; the number of illegal abortions, of course, is unknown. Sterilization is employed in a limited number of cases where indicated for medical as well as social reasons. It is astonishing how much more effectively a poor overworked mother can cope with her problems when she is no longer plagued by a fear of further pregnancies. Medical education now adverts systematically to these matters, although sexology, social psychiatry, and forensic psychiatry are not yet independent subjects at the universities.

\section{Premarital sexual relations}

Some idea of the prevalence of premarital sexual relations may be gained by studying the number of illegitimate births. ${ }^{7}$ These figures are, of course, affected by the use of contraceptive techniques. From $1840-49$, the II.9 per cent rate was very stable; from rgoI-05, the rate was r0.2 per cent; and from 193I-35, the rate was ro per cent. Since then, the rates have steadily decreased, except for a slight aberration in the closing war years-8.9 per cent in 1943 , and 9.2 per cent in 1944. In 1955-57, the rates have been $6.6,6.8$, and 6.9 per cent, respectively. The same general tendency has been observed in Sweden, although the corresponding rates have been somewhat higher.

Significant also is the number of children born during the first nine months of marriage. These are the Danish figures:

Before one month

One to two months

Two to six months

Six to nine months

Total

\begin{tabular}{rr}
1938 & 1957 \\
$2.4 \%$ & $1.2 \%$ \\
$3.0 \%$ & $2.3 \%$ \\
$20.7 \%$ & $29.3 \%$ \\
$7.8 \%$ & $12.5 \%$ \\
\hline $33.9 \%$ & $45.3 \%$
\end{tabular}

T The following figures are based on official statistics supplied by Carry Hedemann. 
This means that in the same period during which the number of illegitimate births has been decreasing to 2,000 to 3,000 per year, there has been an increase in the number of births during the early months of marriage.

Although these figures give only an incomplete picture, Danish and Swedish investigations have revealed sexual habits and practices that closely parallel those discovered by Dr. Kinsey and his associates in the United States. ${ }^{8}$

The most important Danish investigation was made in the years $1944-47$, using a relatively meager sample consisting of $\mathrm{I}_{32}$ unwed, $\mathrm{r}_{53}$ married, and $3^{\circ}$ separated or divorced women, ranging from twenty to thirty-five, and averaging twenty-six years of age. ${ }^{9}$ These women were patients with epidemic illnesses, chosen at random and questioned upon leaving the hospital, and who, therefore, had not possibly heard of the investigation beforehand. Of the 315 women questioned, about one-half had received their sex education from friends, twelve per cent had received it from their mothers, three per cent had received it from their schools, and one-third of them had received none at all. Of the thirty-one of these women who had not had heterosexual relations (one of whom had had homosexual relations), eighteen were under twentythree and three were over twenty-five years of age. Of the 284 sexually-experienced women, I.4 per cent were married when they first had sexual intercourse, 2I 4 per cent were engaged, 44.2 per cent had it with a boy whom they knew well, and the remaining 1.8 per cent had it with a casual acquaintance. The average age of these women at first sexual intercourse was I9.I years, and the length of the acquaintance with her partner on the occasion averaged ten months. Therefore, one cannot say that rashness and promiscuity were characteristic.

In Sweden, many soldiers were interviewed in the years $1942-43,{ }^{10}$ and the results were similar. Here, there was an opportunity to talk to forty-year-olds who had enrolled in the defense guards as well as twenty-year-olds. Ninety-seven per cent of the older men had had sexual relations before marriage, but only eighty per cent of the younger ones had. It is not certain that this difference is significant. The investigation indicated that the sexual relations of the older generation may have been of a more unstable character than those of the younger group. There was no sign of increasing laxity; indeed, if any change could be noticed at all, it was in the direction of recognizing that normal sexual relations demand a partner chosen not only on the basis of sexual factors, but others as well-e.g., the wish to satisfy the need in the partner, or a need of affection, or a wish to protect.

${ }^{8}$ Alfred C. Kinsey, Wardell B. Pomeroy \& Clyde E. Martin, Sexual Behavior in the Human Mare (i948); Alfred C. Kinsey, Wardell B. Pomeroy, Clyde E. Martin \& Paul H. Gebhard, Sexual Behavior in the Human Female (1953).

- Kirsten Auken, Unge Kvinders Sexuelle Adfaerd [Sexual Befavior of Young Wonen] (I955).

${ }^{10}$ Gustay Jonnson, Sexualvanor kas Svensk Ungdorm [Sexual Behavior Among Swedish Youthi] (Comm. for Youth Problems Rep. No. 4I, 195I). 
Among the Scandinavian countries, there has been a close collaboration in the field of administration of justice, which has given rise to similar views on what constitute punishable sex offenses. There are slight differences in the laws of each, but it is difficult to say how significant these differences are in daily life. A comparative analysis of many cases from the several countries would be necessary for an evaluation of this sort. It is probably safe, however, to hazard the generalization that sex criminality is punished similarly throughout Scandinavia.

The Scandinavian penal codes try especially to protect women's sexual freedom and to protect children.

: The opening section on sexual offenses in the Danish Criminal Code provides: ${ }^{11}$

Any person who enforces sexual intercourse with a woman by violence, by depriving her of liberty or by inspiring her with fear concerning the life, health, or welfare of herself or of her nearest relatives shall be guilty of rape....

The minimum and maximum penalties are not less than one year and not more than sixteen years, respectively. Under particularly aggravating circumstances, a life sentence may be imposed, which makes rape one of the most severely punished crimes. Norwegian and Swedish law define and punish rape in much the same way. ${ }^{12}$

Few persons are convicted of and sentenced for rape. In the years 1929-39, of the 3,185 sexual offenses successfully prosecuted in Denmark, only ninety-four were for rape-about ten a year; and despite the increase in population, only twenty-three cases of rape were reported in $1953 .{ }^{13}$ Norwegian and Swedish experience has been similar. ${ }^{14}$

1. Sexual offenses against mentally defective or insane persons, by means of abuse of superior position or trickery, are treated more mildly than rape under the Danish Criminal Code. ${ }^{15}$ The Code also is concerned with sexual intercourse and sexual relations other than intercourse with a child under fifteen years of age (in Norway, the critical age is fourteen; in Sweden, it is fifteen); and if the child is under twelve years of age, the offense is considered an aggravated one. ${ }^{10}$ The abuse of superior age or experience to induce any person under eighteen years of age to engage in sexual intercourse is a punishable offense, too. ${ }^{17}$ "

${ }^{12}$ Danish Criminat Code $\$ 216$ (Knud Waaben transl. r958).

${ }^{22}$ For a more detailed description of the legislation and penological practice governing sex offenses, in Sweden, Norway, Denmark, and Belgium, see Cambridge Dep't of Criminal Science, Sexuar Offencezs pt. 6 (1957) [hereinafter cited as the Cambridge Reporr].

${ }^{13}$ Louis le Matre, Legal Kastration a Straffetlig Belysning [Legal Castration prom a Penal. Law Perspective] table 2, at 87 (1946); le Maire, Danish Experience Regarding the Castration of Sexual Offenders, 47 J. Crim. L., C. \& P. S. 294 (1956).

${ }^{14}$ Even in England, where the law is different, the incidence of rape is modest. In the years 1947-54, there has been a slight increase, but it is less than that for other forms of crime. See C八мmnidos REPORT table I, at $\mathbf{2 2}$.

${ }^{16}$ Danish Criminal Code $\$ 217$ (Knud Waaben transl. I958).

${ }^{16} 1 d . \$ 222$.

${ }^{17} I d$. $\$ 223$. 
Homosexual relations are punishable only when one of the parties is under eighteen years of age. ${ }^{18}$ Punishment may be dispensed with, however, if both parties are of the same age. The abuse of superior age or experience to induce a person of the same sex and under twenty-one years of age to engage in sexually immoral behavior is a punishable offense as well..$^{19}$

The law also proscribes several so-called indecent acts and punishes the person "who by obscene behavior violates public decency."20 And a person who incites or invites another to prostitution or exhibits immoral habits in such a manner as to violate public decency or to give public offense or to inconvenience neighbors may also be prosecuted.21

In the sections concerning offenses against family relations, the law deals with incest, which is defined as sexual intercourse with any relative in lineal descent or ascent, or with brother or sister. ${ }^{22}$ The lineal descendant under eighteen years of age, however, will not be punished.

Table one indicates the frequency of convictions for these crimes. The seemingly great increase in criminal homosexuality in Copenhagen is probably attributable to a very thorough police work spurred by a few cases that were very much discussed in the newspapers.

\section{TABLE I}

Convtctions of Sex Offenses by Offense and Place of Conviction (PER TOO,O0O MALE POPULATION OVER FOURTEEN YEARS OF AGE)

\begin{tabular}{|c|c|c|c|c|c|c|}
\hline & \multicolumn{2}{|c|}{ Capital } & \multicolumn{2}{|c|}{$\begin{array}{l}\text { ProvinclaL } \\
\text { Towns }\end{array}$} & \multicolumn{2}{|c|}{$\begin{array}{c}\text { RuRAL } \\
\text { DIsTRICTs }\end{array}$} \\
\hline & 1938 & 1955 & 1938 & 1955 & 1938 & 1955 \\
\hline 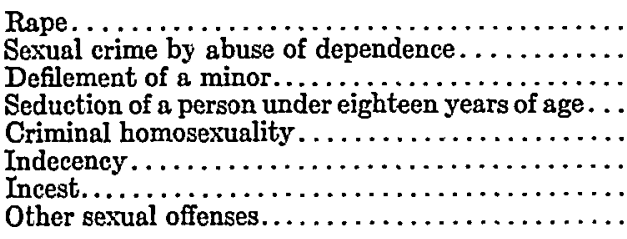 & $\begin{array}{r}4 \\
1 \\
23 \\
0 \\
29 \\
44 \\
5 \\
7\end{array}$ & $\begin{array}{r}5 \\
8 \\
32 \\
112 \\
123 \\
3 \\
3\end{array}$ & $\begin{array}{r}2 \\
1 \\
28 \\
1 \\
21 \\
47 \\
9 \\
2\end{array}$ & $\begin{array}{r}10 \\
3 \\
49 \\
41 \\
67 \\
16 \\
-\end{array}$ & $\begin{array}{r}15 \\
4 \\
86 \\
5 \\
18 \\
68 \\
21 \\
3\end{array}$ & $\begin{array}{r}20 \\
8 \\
69 \\
7 \\
21 \\
61 \\
14 \\
-\end{array}$ \\
\hline 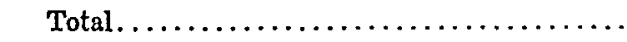 & 113 & 286 & 111 & 186 & 220 & 200 \\
\hline
\end{tabular}

Souncs: Unpublished research of Karl O. Christiansen, Louis le Maire, and Georg K. Stūrup.

Prostitution is not treated as a criminal offense. Police regulation of prostitution was abolished in Denmark in 1906, and since then, the police have sought to control it by invoking the Vagrancy Act. ${ }^{23}$ This act gives the police a right to interrogate a person who has no visible means of support. The person may be enjoined to find legitimate employment, and if this injunction is violated, a sentence may be meted out.

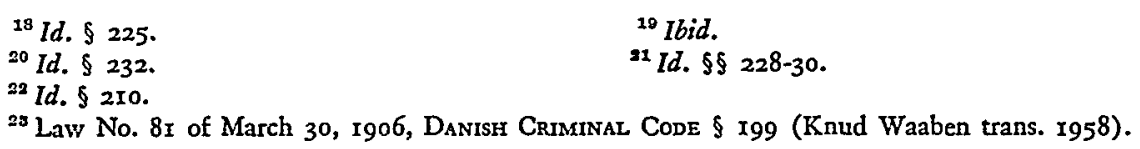


Sexual relations with animals and adultery are still punishable in Norway, but not in Denmark or Sweden. Prosecutions for these offenses are very rare in Norway, however.

\section{III}

\section{Sex Offense Statistics}

It is tempting to try, on the basis of published statistics, to compare the frequency of sex offenses in different countries; but a comparison of this sort would be misleading. Neither the number of reported criminal acts nor sentencing data impart information that can be directly compared. First, it is necessary to remember that a great many offenses of this sort are never reported-for a variety of reasons: The victim may feel ashamed or perhaps think that he or she had provoked the offense and, accordingly, be unwilling to talk about it. Or if it concerns children, parents may be unwilling to pursue the matter and further exacerbate the trauma; and in many cases, the children themselves may never even mention the matter at home. On the other hand, if a serious sex crime has been widely publicized in the newspapers, the number of reports concerning all other sexual offenses invariably increases.

The percentage of cases cleared is another relevant factor that should be considered. This percentage is greater for reported sex offenses than for other crimes, but it differs in different societies. In Denmark, about one-half of the cases reported in the capital and a somewhat larger percentage in the rest of the country are cleared. About two-thirds of the 2,009 cases reported in 1953 were cleared. A great many of these cases, however, did not result in conviction. For persons under eighteen, the charge will be withdrawn when guilt is proved, and the defendant will then be handed over to the child-welfare authorities for disposition. The charge will be withdrawn in other cases as well. Thus, of the 7,274 men convicted of all crimes in 1953, only 620 were convicted of sex offenses. Moreover, very few women are convicted of sex offenses. Thus, of the 757 women convicted of all crimes in 1953, only eleven were convicted of sex offenses, five of them being incest. ${ }^{24}$

If the police are interested in a particular sex offense, there is often an increase in the number of reported cases of this sort. A careful study of sex criminality in general, with special attention paid to the frequency of relapse, however, has shown no important changes in Denmark from 1938-55. Of the 3,185 persons convicted of sex offenses during the period 1929-39, 32.6 per cent had past convictions, but only one half of these were for sex offenses. The majority of the group were under thirty-six years of age-and in this connection, it must be remembered that the minimum age for criminal conviction is fifteen and that very few persons in the fifteen-to-eighteen age group are convicted; therefore, the majority ranged from eighteen to thirty-six. ${ }^{25}$

24 Criminal Statistics 1953 (1955).

${ }^{25}$ Louis te Maire, Legal Kastration i Staffetzig Belysning [Legal Castration from a Penal. LAW Perspective] I07-13 1946 ). 
A follow-up study of this group has been conducted. The sample had, for several reasons, diminished to 2,942. In the course of years until 1953 , only twenty-five per cent had relapsed, and of these, three per cent had been punished with only fines or light imprisonment. This study also showed that those who had been convicted previously suffered twice as many relapses (38.6 per cent) as those who had not (I8.8 per cent). Table two demonstrates that this principle operated uniformly with respect to all the different types of sex offenses. As is seen in table three, the rate of relapse into sex offenses is smallest in the group of offenders who were convicted for the first time (6.9 per cent). Those who had several prior convictions (for sex and other offenses) had a rate of relapse into sex offenses more than three times as great.

The risk of relapse into sex offenses also appears to increase with age. Thus, among the younger offenders, there is probably a group whose criminality must be supposed to be related in some degree to difficulties in adaptation and to other milieu factors that are eventually resolved. The offenses of the other group appears, to a higher degree, to be dependent on more fixed patterns of behavior. Some of these latter offenders could perhaps be called perverted; but it is important not to misuse this term-one must confine it to cases where a special act is needed for sexual satisfaction. The act itself, however, should not be described as a perversion, since it must be seen in relation to what it means to the person to be so characterized.

IV

\section{Treatment of Sex Offenders}

The same treatment, more or less, is accorded different prisoners in the same prison, regardless of the offense for which convicted. Scandinavian prisons are rather small by international standards, containing from less than too to $35^{\circ}$ prisoners. But in Scandinavian prisons, a humanistic approach is adopted, with individual medical, social, and psychological assistance being extended to each inmate. Corresponding supervision is exercised over those whose sentences have been suspended (on probation) and those who have been paroled. The criminological result is, as noted above, better for sex offenders than for others-at least, relapses appear to be less frequent.

From the foregoing, it is clear that scientifically to ascribe any particular result to any one or the other special treatment of first-time sex offenders is very difficult. On the other hand, it is likewise clear that mere conviction of a sex offense is a severe psychic trauma in itself, owing not only to the realization that relatives and friends must know of it, but also to the typically weak and often immature personality structures of sex offenders, which renders the blow to self-esteem especially hard. It is also demonstrable that sex offenders characteristically are individuals whose needs are so sudden and violent as to demand immediate satisfaction. But a large-maybe the largest-number of sex offenses are more circumstantial in nature than manifesta- 
TABLE II

Form of Criminality (I929-39) and Relapses (as of I953)

\begin{tabular}{|c|c|c|c|c|c|c|}
\hline & \multicolumn{3}{|c|}{ First OffEnders } & \multicolumn{3}{|c|}{$\begin{array}{c}\text { Cammalas With Previous } \\
\text { Reconds }\end{array}$} \\
\hline & \multirow[b]{2}{*}{ Total } & \multicolumn{2}{|c|}{ Relapses } & \multirow[b]{2}{*}{ Total } & \multicolumn{2}{|c|}{ Relapses } \\
\hline & & Total & Percentage & & Total & Percentago \\
\hline 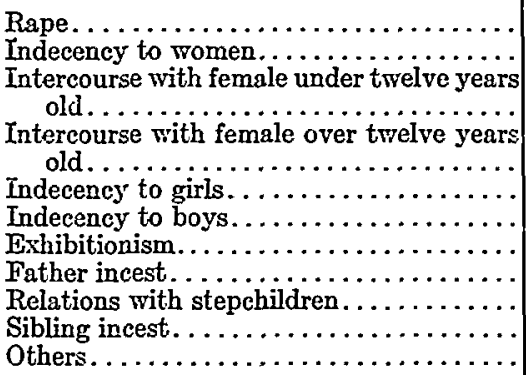 & $\begin{array}{r}55 \\
222 \\
\\
37 \\
385 \\
518 \\
266 \\
263 \\
118 \\
93 \\
71 \\
61\end{array}$ & $\begin{array}{r}7 \\
51 \\
5 \\
69 \\
103 \\
58 \\
57 \\
11 \\
16 \\
12 \\
5\end{array}$ & $\begin{array}{r}12.7 \\
23.0 \\
13.5 \\
17.7 \\
19.9 \\
21.8 \\
21.3 \\
9.3 \\
17.2 \\
16.9 \\
3.2\end{array}$ & $\begin{array}{r}34 \\
78 \\
14 \\
71 \\
193 \\
135 \\
194 \\
55 \\
48 \\
9 \\
17\end{array}$ & $\begin{array}{r}18 \\
36 \\
6 \\
\\
31 \\
76 \\
45 \\
86 \\
9 \\
13 \\
3 \\
4\end{array}$ & $\begin{array}{l}52.9 \\
46.2 \\
42.2 \\
43.7 \\
39.4 \\
33.3 \\
44.3 \\
16.4 \\
27.1 \\
33.3 \\
23.5\end{array}$ \\
\hline Total of group sentenced in $1929-39: \ldots \ldots$ & 2,094 & 393 & 18.8 & 848 & 327 & $3+6$ \\
\hline
\end{tabular}

SodncE: Unpublished research of Karl O. Christiansan, Jouis lo Maire, and Grorn K. Stürup.

TABLE III

RATE of RECIDIVISM (PERCENTAGE)

\begin{tabular}{|c|c|c|c|c|c|c|}
\hline \multirow[b]{2}{*}{ Earlier Offenses } & \multicolumn{6}{|c|}{ J JATER HistorY } \\
\hline & $\begin{array}{c}1 \\
\text { No } \\
\text { offenses }\end{array}$ & $\begin{array}{c}2 \\
\text { Only sex } \\
\text { offenses }\end{array}$ & $\begin{array}{l}3 \\
\text { Sex and } \\
\text { other } \\
\text { offences }\end{array}$ & $\begin{array}{c}4 \\
\text { Only } \\
\text { other } \\
\text { offenses }\end{array}$ & $\begin{array}{c}2+3+4 \\
\text { total }\end{array}$ & $\begin{array}{c}1+2+3+4 \\
\text { total }\end{array}$ \\
\hline 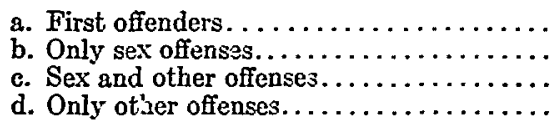 & $\begin{array}{l}81.2 \\
68.6 \\
55.0 \\
59.2\end{array}$ & $\begin{array}{r}5.1 \\
18.4 \\
17.2 \\
5.4\end{array}$ & $\begin{array}{l}1.8 \\
4.3 \\
7.8 \\
4.3\end{array}$ & $\begin{array}{r}11.9 \\
8.7 \\
20.0 \\
31.0\end{array}$ & $\begin{array}{l}18.8 \\
31.4 \\
45.0 \\
49.7\end{array}$ & $\begin{array}{l}100 \\
100 \\
100 \\
100\end{array}$ \\
\hline$b+c+d$ total. & 61.4 & 12.1 & 5.1 & 21.4 & 38.6 & 100 \\
\hline$a+b+c+d$ total. & 75.5 & 7.1 & 2.7 & 14.7 & 24.5 & 100 \\
\hline
\end{tabular}

Soonce: Unpublished research of Karl O. Christiansen, Louis le Maire, and Georg K. Stürup.

tions of a deviated personality or libido. Relations with children, for example, especially when indulged in a drunken state, are quite likely to be the result of sudden changes in sexual reactivity, with an increased susceptibility to stimuli usually without sexual value, and not necessarily indicative of permanent abnormalities.

In short, therefore, it can cogently be maintained that the great majority of sex offenders encountered, whether in prisons or in detention institutions, display a very great need for psychiatric treatment. Many of them consciously feel a need for help in coping with something that overwhelms them, almost against their will. With others, the principal psychiatric task is to bring about a recognition of this need. In a closed institution, this often can be done by persuading inmates that they them- 
selves and society have common interest in their successful treatment. "Society has an interest" is often grasped by sex offenders, who admit that "after all, society cannot put up with that kind of thing." The ethical insight of these inmates is usually extremely clear; and when their protective shell is penetrated, one finds them full of self-reproach, which has hindered the establishment of rapport.

Even if special psychiatric treatment should not effect a statistically smaller rate of relapse-although it most probably would-such treatment has an independent humanitarian value. The treatment need not in most cases be very complicated. Much can be accomplished by sympathetic listening to the patient and by sober and rational discussions of his sexual and ordinary personality problems, if the atmosphere in which the therapy is conducted is kept objective. During the therapy, a distinction must be drawn between what in all cases must be called regrettable or quite unacceptable acts and the men who commit them; and the latter must not be condemned. When the patient establishes emotional contact with the therapistprofessional or nonprofessional-it is important that he still have an opportunity to discuss the regrettable fact that he, against everybody's interests-including his ownhas possibly shown irresistible tendencies to commit unacceptable acts.

In a smaller number of cases, this supportive therapy will reveal special problems that may need more radical treatment. In some of these cases, it will be reasonable, for a shorter or longer period, to supplement psychotherapy with what in common parlance is often called hormonal castration-a procedure that is based on the inhibiting effect of female sex hormones on male sex manifestations. ${ }^{26}$ This treatment hăs a few disadvantages, especially an annoying enlargement of the breasts, which tranis̀vestites reckon a special advantage. Some endocrinologists have also suggested that long and intense hormone administration may increase the risk of cancer. But on the other hand, if the hormones are injected weekly, it may afford a valuable opportunity for psychotherapeutical contact. It is important, however, to integrate the special and/or biological therapy into a total of medical, psychological, and social support program. Hormonal treatment is not enough; libido will quickly revive whèn hormones are discontinued, and a relapse sometimes follows. ${ }^{27}$

In several cases, hormonal treatment has succeeded in so calming the patient that simple clarification of a neurotic disturbance has been achieved. For example; a twenty-five-year-old thief, characterized by strong fetischistic and masochistic elements, was considered by a psychiatrist who had had long experience with psychóanalysis to be inaccessible to therapy. He was committed to an institution, where "he was subjected to two years of combined hormone and psychotherapeutic treatmenit. Now, after three years of freedom, he has had no relapses, is earning a living for himself, his wife, and children, and seems to have been liberated of his fetish. ${ }^{28}$

\footnotetext{
${ }^{20}$ Golla \& Hodge, Hormone Treatment of the Sextal Offender, I LANCET Ioo6 (r949); Hodges, in RAPPORT DE BIOTYPOLOGIE 306 (nid.).

${ }^{27}$ H. R. Teirick, Der Psychologe 320 (1959).

${ }^{2 s}$ Stürup, Teamwork in the Treatment of Psychopathic Criminals with Special Reference to Herstedvester, II Bulletin Societé Internationale de Criminologie 299, 340-52 (I959).
} 
With great caution in different places-England, Germany, Holland, and the Scandinavian countries, and possibly also in other countries-elaboration of these methods is being assayed, with a view towards employing certain hormone preparations in the same way that antabus is used in the treatment of alcoholics. This has raised the possibility of its employment in ordinary out-patient treatment, but it has not yet been tried in Scandinavia for the large number of cases for which it would be suitable. Less deep-going psychotherapy is being given instead in some cases of suspended sentences or in connection with the short prison sentences that are most frequently imposed.

Even hormonal treatment would not be satisfactory, however, for dealing with either more serious and inveterately morbid cases, or habitually deviating behavior that has become ingrained over many years. Here, time-consuming, analyticallyoriented treatment is rather indicated. But there are very few doctors sufficiently well qualified in this field who could undertake such treatment, and they are already heavily committed. Furthermore, the treatment should proceed on an out-patient basis, with the patient living as normal a life as possible under the circumstances. There are also other practical obstacles, in that some of these patients are not amenable to such treatment owing to age, defective intelligence, and peculiarities of personality. Financial problems also may figure largely. Moreover, treatment sessions have to be frequent, and to combine them with normal employment often involves great difficulties. What the patient loses financially during the period he is undergoing treatment in itself often makes it impossible for him to continue the treatment. There is the question, too, of whether the patient lives in a city where he can find a suitable psychotherapist.

A much-disputed alternative remains-namely, the possibility of operative treatment of some of the fortunately very few cases that in most countries are considered hopeless because of the frequency or seriousness of the relapses. Many such offenders are imprisoned for long periods of time, and in some countries punished with death.

In Denmark, a law was passed in Ig29 making it possible for a sex offender to consent to castration. ${ }^{29}$ He himself must apply for it on grounds that his sexual urge causes him to commit crimes rendering him dangerous to society or entailing considerable psychic or social suffering. A detailed medical certificate of approval must also be supplied by an experienced psychiatrist, and the individual must be fully informed of the consequences. Further, if he is married, his wife must give her consent as well, if possible. Norway, Finland, Iceland, and Sweden have enacted legislation similar in principle to the Danish. ${ }^{30}$

\footnotetext{
${ }^{29} \mathrm{Law}$ No. I30 of June I, I929, § $\mathrm{r}$, as amended, Law No. I76 of May Ix, I935, § 2.

${ }^{30}$ In 1933, a castration law was enacted in Germany, based on Nazi principles, under which one could be sentenced to castration; later voluntary consent to this procedure was made possible. See A. Langelüddeke, Gerichtzliche Psychiatric [Forensic Psychiatry] i04 (x959). In Holland and Switzerland, castration has also been used therapeutically to a considerable extent, but without spccial authorizing legislation. See A. Wejffels, Het Castratievraagstuck [The Castration Question] (1954); C. Wolf, Die Kastration [Castration] (1934).
} 
Under Danish, Finnish, and Icelandic laws, compulsory castration is possible. This provision has been a dead letter in Denmark, however, and it may soon be repealed. In Finland, on the other hand, most castrations have been compulsory and only a few have been voluntarily sought. This has resulted in a strong public reaction against the procedure and its consequent infrequent employment in the last few years. In Norway, castration has also been used in cases where the basis has been quite doubtful-e.g., to pacify restless mental defectives and insane persons. Nevertheless, authorities agree that the outlook is good for the patient and society when the operation is voluntary, medically well-indicated, and regarded by the patient as treatment. ${ }^{31}$

In Denmark, continuous contact has been kept through the years with every person who has been legally castrated. ${ }^{32}$ Therefore, it has been possible to record and assess the information given by these patients. In periods when things are going well, their reports concerning the results of the operation seem more optimistic. In other periods, however, when life seems difficult, the opposite is more likely. This illustrates the caution that must be exercised in evaluating apparently well-considered reports from the patient. The predominant reaction following castration, however, is gratitude for the help received; very few have, for any extended period, regretted the operation. There is, therefore, reason to believe that some of those who have been reported as being dissatisfied with the operation were experiencing a merely temporary reaction that would have been dissipated had they been interrogated at a later time.

Not infrequently there is a tendency among the castrated to boast of continuing sexual prowess. It is known, of course, that potency can linger for some years after castration; but the dominating libido invariably will have lost so much of its power that even weak personalities will not be stimulated to spontaneous activity.

The most difficult sex offender cases in Denmark have been treated in Herstedvester, an institution operating under the aegis of the Ministry of Justice that receives psychically abnormal offenders who are neither mentally defective nor insane, but who are suffering from a nontemporary weakness or derangement of their mental faculties. ${ }^{33}$ These are, as a rule, chronic offenders. From I933 to I95I,

${ }^{3 x}$ See Johan Bremer, Asexualization (1958); Wolf, op. cit. supra note 30; Knud Sand, Die Gesetzliche Kastration [Legal Castration] (1940); Dai danische Sterilisationsgesetz vom I Juni I929 und seine Resultate [The Danish Sterilization Law of June I, I929 and Its Results], 25 MoNatsSCHRIFT Für KRIMINAL-PSYCHologie 49 (1935); La Sterilisation et al Castration legale au Danemark [Legal Sterilization and Castration in Denmark], I937 ANN. DE MÉp. LEG. 一; Stürup, Sexual Offenders and Their Treatnent in Denmark and Other Scandinavian Contries, Int'l Rev. Crim. Pol., no. 4, I953, p. I; Letter from A. Fischer-van Rossen to Georg K. Stürup, Feb. I2, I959.

${ }^{32}$ Detailed reports on the results of legal castration in Denmark were published 5 and ro years after the passage of the enabling law. Knod Sand, Die Gesetzliche Kastration [Legal Castration] (1940); Das dänische Sterilisationsgesetz vom. I Juni 1929 une seine Restltate [The Danish Sterilization Law of June 1,1929 and Its Restlis], 25 Monatsschrift für KRIMINaLpsychologie 49 (1935); La Sterilisation et la Castration legale au Danemark [Legal Sterilization and Castration in Denmark], 1937 ANN. DE MÉD. LEG. - There will presumably be a continuation of these studies now that 25 years have passed.

${ }^{33}$ See Georg K. Stürup, Forvaringsanstalten I Herstedvester, i935-51 [The Institution at HerstedVEster, I935-5x] (I959). 
Herstedvester received a total of 704 offenders who had been sentenced to an indeterminate detention. Of these, 243 had been sentenced for a sex offense-and in some cases, for another crime as well. Of this group, 223 were paroled before 1956; five still remained in detention; twelve had been transferred to mental hospitals; and three had died during their detention.

The following tabulation indicates the duration of imprisonment of sex offenders at Herstedvester:

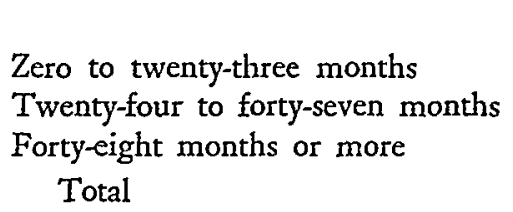

Zero to twenty-three months

Twenty-four to forty-seven months Total

\begin{tabular}{l} 
Castrated \\
$127(86 \%)$ \\
$9(6 \%)$ \\
$11(7 \%)$ \\
\hline $147(99 \%)$
\end{tabular}

$$
\begin{aligned}
& \text { Not Castrated } \\
& 7(9 \%) \\
& 23(28 \%) \\
& \frac{51(63 \%)}{81(100 \%)}
\end{aligned}
$$

Of the 147 castrated offenders, five (3.5 per cent) have suffered relapses and committed new sex offenses, and thirteen ( 9.2 per cent) have committed other crimesin all, r2.7 per cent have recidivated. Of the eighty-one noncastrated offenders, twenty-four (29.6 per cent) have suffered relapses and committed new sex offenses, and seventeen (2I per cent) have committed other crimes-in all, $5^{0.6}$ per cent have recidivated. When one considers the nature of this material, a fifty-one per cent rate of relapse is not overly disappointing, but it is not as encouraging as the results obtained where the usual social psychiatric treatment was combined with castration.

In Avereest, an institution in Holland similar to Herstedvester, the results have been similar. ${ }^{34}$ In the years $193^{8}-5^{6}$, of the 237 persons who submitted to castration, twenty-two did not turn out successfully: three committed new sex offenses, two were suspected of new sex offenses, and the others were guilty of other antisocial behavior.

In Norway, of I02 castrated sex offenders, only three have suffered relapses and committed new sex offenses. One authority estimates that about twenty-five of this group would have relapsed had they not been castrated; he points out also, however, that it is doubtful whether the operation was necessary in thirty of the cases, and that sixteen cases were not paroled despite the operation. He notes that in the follow-up investigation, twenty-three cases-including the nonparoled sixteen-were found bitter and felt they had been cheated. ${ }^{35}$

An assessment of the value of castration cannot be attempted here. It poses a difficult clinical task, and only a thorough analysis of the peculiar conditions in each country, including detailed case histories of the patients, can produce an objective answer. It is quite clear, however, that castration will never be numerically a very significant technique for dealing with sex offenses. On the other hand, in the few cases where this procedure has thus far been employed, it has, in combination with careful social-psychiatric treatment, helped many whose sex problems were so severe

\footnotetext{
${ }^{34}$ Letter from A. Fischer-van Rossen to Georg K. Stürup, Feb. 12, 1959.

Treatment of Sex Offenders], I952 BeIträge zur SexunLfarschung 24.

${ }^{35}$ BREMER, op. cit. supra note 3I, at 3I5-2I.
} 
that they could not have been helped in any other way. Prolonged segregation is another rather heroic alternative that has been recommended by some psychotherapists $_{;}^{36}$ but it works a more severe interference in the normal life of a man.

\section{ConClusion}

For the largest number of sex offenders, social-psychiatric assistance is distinctly needed, although not all sex offenders are necessarily abnormal. ${ }^{37}$ On the contrary, there are many similarities between normal behavior and much of what our culture looks upon as punishable. The differences are more those of degree than of kind. Accordingly, it should be possible to counteract hysterical public reactions, often stimulated by dramatic press descriptions of sex offenses, by objective analysis of sex criminality, its background, its treatment, and the results that may be achieved. Some sex offenses become especially dangerous because the offender himself is caught up in the same panic that later influences those who read about the crime. Unfortunately, this attitude often spreads to the large number of less dangerous sex offenders who are practically harmless and only rarely relapse.

${ }^{38}$ Louis S. London \& Frank S. Caprio, Sexund Deviation 606 (x950).

${ }^{37}$ But see Baan, Zur Frage der Behandlung von Sittlechkeitsdelinquenten [On the Question of the Treatment of Sex Offenders], I952 BEITRĀGE ZUR SEXUALFORSChung 24. 
. 